\title{
Investigation Procedures in Implementing Diversion on Case Against Children's Traffic Accident Police in Purworejo
}

\author{
Mochammad Ipnu Wardani ${ }^{1}$ and Akhmad Khisni ${ }^{2}$
}

Abstract. Police as investigators in settling disputes traffic accidents of children, are required to make efforts diversion on. This research problems using a knife analysis theory and the theory of the workings of the criminal responsibility law. Implementation of diversion on by investigators as a form of settling disputes traffic accidents child is in conformity with the provisions of Act No. 11 of 2012 on the Child Criminal Justice System. Investigators obstacles encountered in the application of investigative procedure as a form of settling disputes traffic accidents are children in Purworejo district police diversion on process does not produce an agreement and the diversion on agreement is not implemented. Another constraint is has not formed some infrastructure to support the implementation of the Act SPPA, including the lack of Correctional Centers (BAPAS), Institute of Child Development While (LPAS) and Special Child Development Institute (LPKA) located in the region of Purworejo. In practice, investigators already holding BAPAS Class II Purwokerto, because long distance, it is feared the diversion on process becomes longer than that prescribed by the Act., To overcome these obstacles investigator to approach the families of the victims, seeking coordination with BAPAS and if there is no agreement versioned then handed over to the Prosecutor's case.

Keywords: Investigation, Diversion on, Child.

\section{Introduction}

Indonesian National Police as an investigator in the Criminal Code is the Indonesian National Police officers or officers of certain civil servants who are given special authority by law to conduct an investigation.

In implementing its juvenile justice system, the police have the authority to arrest, detention, investigation, and investigation. In the implementation of Police has the authority discretion. Discretionary authority is given the legal authority by the Act, in this case the police are entitled to continue or not to continue a case as long as it does not pose a risk and conflict in the completion of the crime, as well as considering the principles of benefit and does not interfere with the public interest. Police can redirect (diversion on) of a criminal case committed by a child so that the child does not have to deal with the completion of the formal criminal justice.

Police officials in the public interest of the Republic of Indonesia in implementing the tasks and authority can act according to his own judgment. ${ }^{3}$ Implementation of the

\footnotetext{
${ }^{1}$ Students of Masters (S2) of Law Faculty of Law Unissula Semarang email ibnuwardani686@gmail.com

2 Lecturer of Faculty of Law UNISSULA Semarang

${ }^{3}$ Article 18 paragraph 1 of Act No. 2 of 2002 on the Indonesian National Police
} 
provisions referred to can only be done in a state that really needs to pay attention to laws and regulations, as well as the Code of Professional Ethics of Indonesian Police. ${ }^{4}$ It is also stipulated in Article 7 of Act No. 11 of 2012 on Child Criminal Justice System which includes: 1) At the level of investigation, prosecution and court case investigation Child in the country must be pursued Diversion on. 2) Diversion on referred to in paragraph (1) shall be implemented in the case of criminal offenses committed: a. punishable by imprisonment under the 7 (seven) years; and b. not a repetition of criminal acts.

Criminal sanctions imposed on the officials who had been mandated by the Act to provide diversion on efforts provided for in Article 96 of Act No. 11 of 2012 which reads:

"Investigators, the Public Prosecutor and the Judge who deliberately do not carry out the obligations referred to in Article 7 paragraph (1) shall be punished with imprisonment of 2 (two) years or a maximum fine of Rp 200,000,000.00 (two hundred million rupiah) ."

Purworejo district police jurisdiction in criminal case there are traffic accidents of children are resolved through the process of diversion on by police investigators, namely in 2018. Based on the criminal case of traffic accidents mentioned above, the diversion on of the national police investigator against children in conflict with the law who will be studied, discussed and presented in the study with the title "Diversion on Investigation Procedures in Implementing the Children's Traffic Accident In Purworejo district police. "

Based on the description of the background which has been described above, then the problem is formulated as follows: 1) What is the procedure of investigation in the implementation of the diversion on of the traffic accident cases of children in Purworejo district police? 2) Barriers what investigators experienced in applying the investigation procedures in the implementation of the diversion on of the traffic accident cases the child at the police station Purworejo and how attempts to solve it?

\section{Result And Discussion}

\subsection{Investigation Procedures in Implementing the Case Against Diversion on Children Traffic Accidents In Police of Purworejo.}

Based on the results of research conducted in the case of traffic accidents of children in Purworejo district police on out 2018, investigator then have attempted diversion on. This is shown by the case of a traffic accident with Police Report Number: LP / 90 / III / 2018 / CENTRAL / RES PWR / So on court traffic accidents of children that occurred on Saturday, March 10, 2018 which led to casualties An Achmad age of 73 years died and the child actors An Girah daughter Sari binti Sudiman 17 years old diversion on agreement has been reached with the issuance of Decree No. Termination of Investigation: S. Tap / 01 / V / 2018 / Res Pwr.

\footnotetext{
${ }^{4}$ Article 18 paragraph 2 of Act No. 2 of 2002 on the Indonesian National Police
} 
The above data illustrates that the settlement traffic accident investigator children always strived through investigation procedure which ended with the decision of diversion on with criminal offenses committed considerations call for imprisonment under 7 years and is not a repetition of criminal acts. ${ }^{5}$ Mentioned in the event of accidents resulting in another person's death, shall be punished with imprisonment for a period of 6 (six) years and / or a maximum fine of Rp. 12,000,000.00 (twelve million). ${ }^{6}$ This enables the implementation of the agreement through diversion on.

Diversion on process in the investigation, started after receiving the police report. Investigators made the letter asking for written advice from the supervising officer community. The results of sociological research community must be submitted by the supervisor to the investigator within a maximum of $3 \times 24$ (three times twenty four) hours after the investigation request is received. ${ }^{7}$ As investigators began to seek diversion on in no later than 7 (seven days after the investigation began. The process diversion on implemented not later than 30 (thirty) days after the start of diversion on. Furthermore, in terms of process Diversion managed to reach an agreement, the investigators delivered the news show diversion on along with the deal Diversion on the chairman of the district court to make the determination. and in terms of Diversion failed, investigators are required to continue the investigation and to transfer the case to the public prosecutor to attach the minutes of the Diversion on and social research report. $^{8}$

For example, the completion of the diversion on of traffic accident cases of children in Purworejo district police, perpetrator or the victim agrees to do versioned, then the police, community counselors and social workers begin the consultation process for settling disputes involving related parties. After the diversion on agreement between the offender with the victim, then the investigating authorities to apply for the establishment of Purworejo Traffic diversion ons No. B / 302 / IV / III / HUK.II.I / 2018 / Res Pwr for Purworejo District Court. Determination of diversion on is done within a period of three days, from receipt of the diversion on agreement. Determination issued Purworejo District Court No. 2 / Pen.Div / 2010 / PN was submitted to the supervisor Pwr community, the investigator, the prosecutor, or a judge within a period of three days from the set. After receiving a determination from the court, the investigators published the determination of termination investigation by Warrant Termination of Investigation No. SPPP / 01.a / V / 2018 / So.

Based on the above-mentioned case and the results of research conducted, the investigator then Purworejo Traffic Police in carrying out investigations of traffic accident cases the child was based on procedures with the provisions of Act No. 11 of 2012 on the Criminal Justice System Child.

If in the process of diversion on by investigators not reached a peace agreement between the offender with the victim, the investigator or the police to bring the case

\footnotetext{
${ }^{5}$ Article 7 Paragraph (1) and (2) of Act No. 11 of 2012 on Child Criminal Justice System.

${ }^{6}$ Article 310 Paragraph (4) of Act No. 22 of 2009 on traffic and road transport.

${ }^{7}$ Article 28 of Act No. 11 of 2012 on Child Criminal Justice System

${ }^{8}$ Article 29 Paragraph (1) (2) (3) of Act No. 11 Year 2012 on Child Criminal Justice System.
} 
to the Public Prosecutor. Investigators attach the minutes of diversion on and research reports from officers supervising civic society.

\subsection{Become Factors Inhibiting Investigation Procedures in Implementing the Case Against Diversion on Traffic Accidents Police Purworejo And Children In Effort to Overcome It.}

There are several factors that hinder the investigation procedures in the implementation of the diversion on of the child at the police station accident case Purworejo, namely:

- Juvenile justice diversion on process fails, it is because: a) Diversion on process does not produce an agreement, is the diversion on process being done not to be able to produce a deal like that referred to in Article 11 of Act No. 11 of 2012. The failure caused the victim's family against diversion on, they saw that children in conflict with the law should be punished like adults; b) Diversion on agreement is not implemented, is in the child's case already obtained the agreement of diversion on as mentioned in Article 11 Act No.11 of 2012, but then it was not implemented.

The failure caused the victim's family against diversion on, they saw that children in conflict with the law should be punished like adults. Diversion on agreement could also be charged a cancellation or null and void if the agreement violates the terms valid agreement as provided for in Article 1320 of the Civil Code.

- In the region of Purworejo has not formed some infrastructure to support the implementation of the Act SPPA, including the absence of the Child Development Institute While (LPAS) and Special Child Development Institute (LPKA). In practice, the procedure of investigation of traffic accidents of children in Purworejo district police already holding BAPAS Class II Purwokerto. Investigators constraint is long distance, it is feared the diversion on process becomes longer than that prescribed by the Act. ${ }^{9}$

As an attempt to overcome these obstacles are as follows: ${ }^{10}$

- Juvenile justice diversion on process fails or continue, as:

- Did not produce an agreement, then the investigation, prosecution and juvenile criminal case investigation continues. As evidence of accountability, the parties made a joint statement that the contents are not versioned, and signed an agreement together for consideration later if ever truly juvenile justice diversion on process turns then continued.

- Diversion on agreement is not implemented, Article 14 paragraph (3) of Act No. 11 of 2012 specifies that social counselors immediately make a report to investigators, prosecutors, and judges that the diversion on agreement is not implemented. As a follow-up is investigators, prosecutors, and judges to revoke

\footnotetext{
${ }^{9}$ Interview with Chief Unit Laka Traffic Police Purworejo Aiptu Tukul Praise Puryono SH MH issues that affect the procedure investigating traffic accidents of children is a matter of mileage Bapas reach where within a maximum period of 3 (three) days investigator must obtain the results of the research community / Litmas of Bapas.

${ }^{10}$ Interview with Aiptu Tukul Praise Puryono SH MH as Police Chief Unit Laka Purworejo Purworejo on July 62018.
} 
or declare invalid the determination of the termination of the investigation, prosecution termination determination, and the determination of termination checks have been issued, which in turn forwarded juvenile criminal justice process.

Previous investigators working on an agreement that diversion on by approaching the victim's family to provide an understanding that the criminalization of children can destroy a child's future. And explain the legal basis diversion on investigators perform in accordance with the mandate of Act No. 11 of 2012 on Child Criminal Justice System.

- The absence BAPAS in Purworejo regency, the investigators sought to coordinate and approach to the class II Purwokerto BAPAS that the process of diversion on can be completed on time stipulated Act.

\section{Closing}

\subsection{Conclution}

- Investigation procedures in the implementation of diversion on to the case of accidents. Traffic Police Purworejo child is in conformity with the provisions of Act No. 11 of 2012 on the Criminal Justice System Child. The investigation procedure has been set out in Article 26 through Article 29 of Act No. 11 of 2012.

- Obstacles encountered investigator in the application of diversion on through the procedure of investigation in the implementation of the diversion on of the traffic accident the child at the police station Purworejo is disagreement diversion on and deal versioned not implemented it is because the victim wants case of accident processed through the courts, moreover diversion on agreement could also be charged a cancellation or null and void if the agreement is valid treaty violates the terms as set out in article 1320 of the Civil Code.

\subsection{Suggestion}

- UUSPA socialization needs related to community procedures for settling traffic accident through a diversion on so that children actively participate in the achievement of diversion on.

- To facilitate the diversion on process is need for better coordination between the Police Investigators then lacquer-BAPAS Purworejo with class II Purwokerto.

\section{Bibliography}

[1] Chairul Huda 2011 Dari'Tiada Pidana Tanpa Kesalahan'Menuju Kepada'Tiada Pertanggung Jawaban Pidana Tanpa Kesalahan', Kencana Jakarta

[2] Dahlan Sinaga 2017 Penegakan Hukum Dengan Pendekatan Diversi Yogyakarta : Nusa Media Yogyakarta

[3] Rinto Raharjo 2014 Tertib Berlalu-Lintas Yogyakarta : Shafa Media.

[4] R. Wiyono 2016 Sistem Peradilan Anak Di Indonesia Sinar Grafika. Jakarta 
[5] Selamet Riadi Peran Penyidik Polri dalam Penerapan Diversi terhadap Anak Yang Berkonflik Dengan Hukum (Studi di PPA Polres Lombok Barat) Jurnal IUS Vol IV Nomor 2 Agustus 2016.

[6] Sri Rahayu Diversi Sebagai Alternatif Penyelesaian Perkara Tindak Pidana Yang Dilakukan Anak Dalam Perspektif Sistem Peradilan Pidana Anak Jurnal IImiah Hukum Volume 6 Nomor 1 Februari 2015.

[7] Act No. 2 of 2002 on the Indonesian National Police

[8] Act No. 11 of 2012 on Child Criminal Justice System.

[9] Act No. 22 of 2009 regarding traffic and road transport.

[10] Interview with Traffic Police Chief Unit Laka Purworejo Aiptu Tukul Puryono SH $\mathrm{MH}$ 